\title{
Management of Radix Entomolaris in \\ Mandibular Second Molar with Multiple Canal Ledges: A Case Report
}

\author{
MoatazBellah A Alkhawas*, Mostafa S Ahmed \\ Al-Azhar University, Egypt
}

Submission: February 17, 2017; Published: April 13, 2017

*Corresponding author: MoatazBellah A Alkhawas, BDS, MSC\&PhD in Endodontics, Lecturer of Endodontics, Faculty of Dental Medicine, Al-Azhar University, Nasr City, Cairo, Egypt, Tel: 00201001189085; Email: malkhawas@yahoo.com

Keywords: Radix entomolaris (RE); Cone beam computed tomography (CBCT); Three dimensional (3D)

\section{Introduction}

Sometimes, flare up may occur because of incomplete elimination of pathogenic microorganisms owing to complexity and variation of the pulp anatomy leading to missing pulpal tissue which acts as a nidus for infection [1]. These variations considered as a challenge in detection and management of such cases. An extraordinary root has been reported in mandibular molars that was located either mesiolingual to the distal root (radix entomolaris) or mesiobuccal to the distal root (Radix paramolaris). Radix entomolaris (RE) was firstly described by carabelli G 1844 [2]. Unfortunately, detection of the third root is not easily with two-dimensional radiographs due to overlapping with other anatomical structures. Nowadays, cone beam computed tomography (CBCT) is a valuable tool to detect teeth with extra root and root canals more accurately due to its three dimensional (3D) nature [3]. This case report showed diagnosis and management of radix entomolaris related to 37 .

\section{Case Report}

A 23 years old female patient came to a private endodontic clinic with a persistent pain related to left side of the mandible. Reassurance of the patient in concomitant with preoperative medical and dental history taking was done by a dentist. Following history taking, an experienced endodontist clinically examined the patient that was accompanied with restricted mouth opening. She suffered from acute apical periodontitis related to tooth 37 that had large, defective amalgam filling. A periapical radiograph was unclear to identify the number of roots and root canals Figure 1 while cone beam CT (СВCT) revealed bilateral presence of extra root in the mandibular second molars (Figure 2). In addition,
CBCT confirmed widening in lamina dura and S-shaped canals in tooth 37.

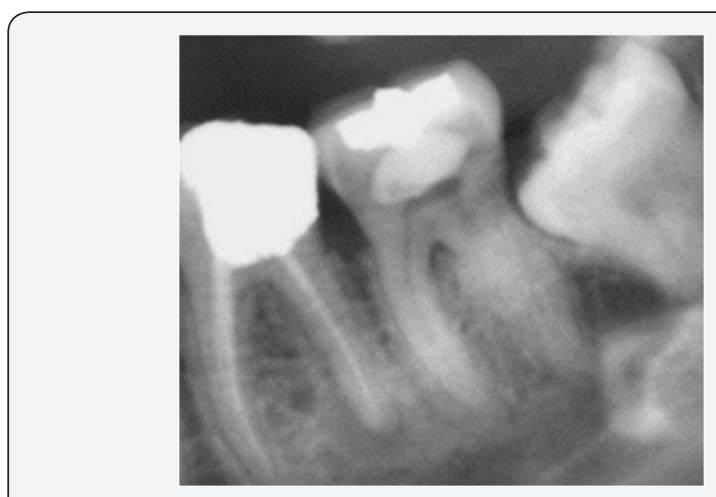

Figure 1: A preoperative radiograph showing the mandibular left second molar while root outline is hesitated distally.

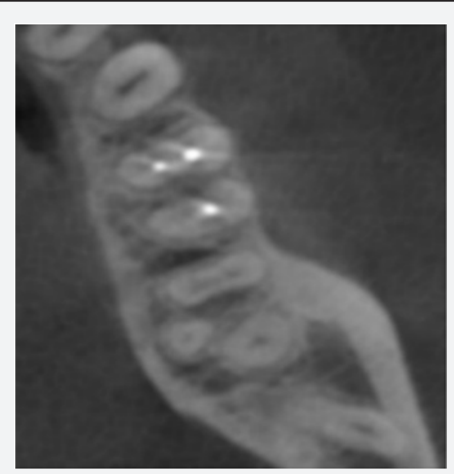

Figure 2: A preoperative axial view of $\mathrm{CBCT}$ radiograph showing three rooted mandibular second molar. 


\section{Treatment Protocol}

The patient signed the ethical consent for acceptance of both the treatment protocol and the publishing purpose. All treatment procedures were done under magnification range from 6.9-17 X using dental operating microscope (OMS2350 Dental Microscope, Zumax, China). Prior to access cavity preparation, the endodontist removed the defective amalgam filling followed by rubber dam isolation of the affected tooth. Rebuilding of the coronal part of the tooth using self-cure resin modified glass ionomer (Riva, SDI Ltd., Australia) was done.

Following setting of the glass ionomer, access cavity was prepared using round bur no.4 mounted on high-speed handpiece. Scouting of the canal orifices was done using E15D ultrasonic tip (NSK, Japan) that was mounted on ultrasonic scaler handpiece (P5 Booster, Satelec, France) followed by exploration of the root canals using endodontic explorer. The canals were initially negotiated using pre-curved C-plus file ISO \#6, 8, \&10 (DENTSPLY Maillefer, Switzerland).

During canal negotiation, a sudden canal blockage was noticed with resultant ledges at the abrupt curvatures of the root canals. The ledges were bypassed using $\mathrm{K}$ files \#6,8\&10then Working length was determined using electronic apex locator (Dentaport $\mathrm{zx}$, J. Morita, Japan) and it was confirmed with periapical radiograph. Root canal instrumentation had done using Revo-S (Micro-Mega, France) rotary system according to the file sequence recommended by the manufacturer (SC1, SC2, SU\&AS30) until reach AS30 as a master apical file.

Among the used rotary files, canal patency was done using \#10 $\mathrm{K}$ file in concomitant with irrigation of the root canal system using $2 \mathrm{ml}$ sodium hypochlorite irrigating solution 5.25\% (ChloraXid 5.25\% PPH CERKAMED Wojciech Pawłowski, Stalowa Wola, Poland). Using17\% EDTA as a lubricant (Meta biomed co. ltd, Korea) that was rinsed with distilled water before using the sodium hypochlorite irrigating solution. Checking the master point with visual and tactile methods with radiographic confirmation (Figure 3).

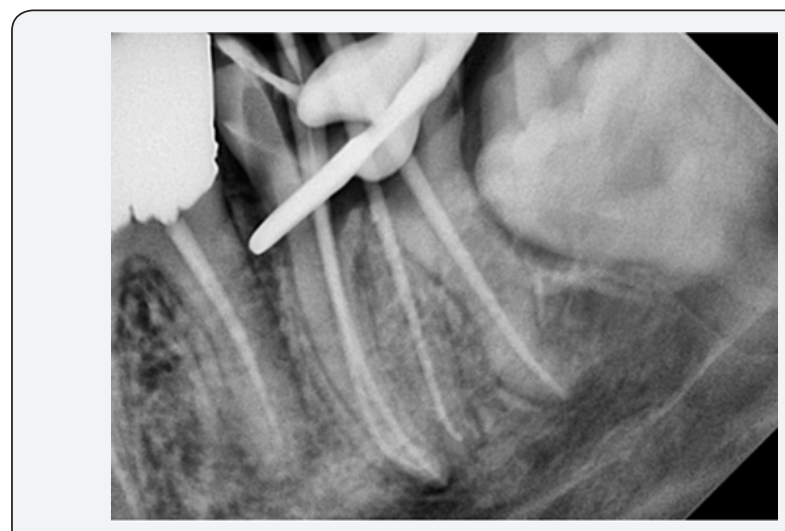

Figure 3: A periapical radiograph showing the master points inside the root canals after bypassing all ledges of the roo canals followed by chemo-mechanical preparation.
All root canals were dried with paper points that matched the size of master apical file. Obturation of the root canals was done using continuous wave compaction technique (E\&Q plus, Meta Biomed co. ltd, Korea) with warmed gutta percha (Meta Biomed co. Itd, Korea) in conjunction with resin sealer (ADseal, Meta Biomed co.ltd, Korea) (Figure 4).The access cavity was sealed with resin modified glass ionomer (Riva, SDI Ltd., Australia). Finally, the patient was referred to prosthodontist for final restoration.

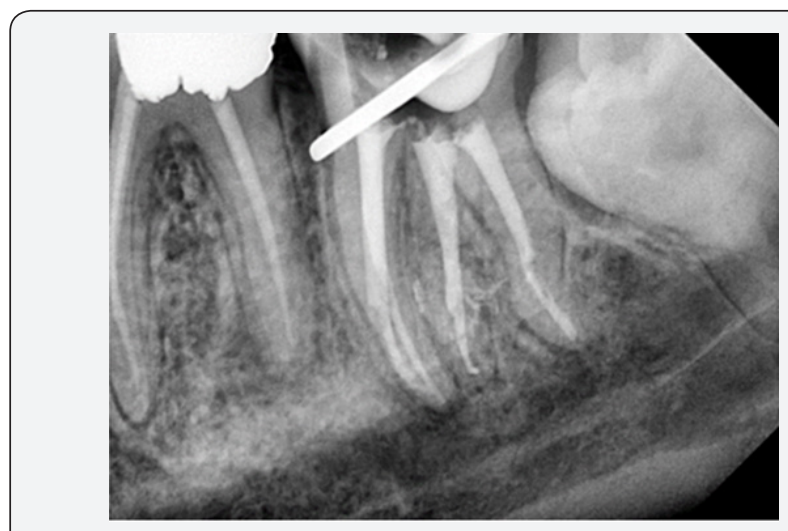

Figure 4: A periapical radiograph showing obturation of the root canal system using continuous wave compaction technique.

\section{Discussion}

Complexity of canal morphology and anatomical variations of teeth may lead to failure in endodontic treatment if not detected [4]. Radix entomolaris (RE) is one of the evidence based anatomical variations for mandibular first molar but a few studies had discussed RE in the lower second molar. Radix entomolaris occurs bilaterally in $50 \%$ to $67 \%$ of mandibular first molars [5]. Carlsen and Alexandersen had classified the RE into four types A, $B, C$, and AC based on location of its orifice in relation to other canal orifices. In type A, RE is located mesiolingual to the distal root with two canals, type $\mathrm{B}, \mathrm{RE}$ is located mesiolingual to the distal root with one canal, type $\mathrm{C}$ is located distolingual to the mesial roots, while type $\mathrm{AC}$ is located in a point midway between the mesial and distal canals [6].

The mean length of radix roots is $18.09 \pm 1.68 \mathrm{~mm}$ [7]. RE is highly associated with prevalence with ethnic groups. The prevalence of RE in mandibular first molar is $3.4 \%$ in black population [8] while in Euroasian and Indian it is lower than 5\% [9]. In Caucasian population ranges from $3.4 \%$ to $4.2 \%[10,11]$. However, in people mangoloid traits (such as chinese, Eskimo and Korean) RE incidence ranges from 5.8\% to $33.1 \%[9,12,13]$. In an Egyptian population, Younes et al. [14] had reported $0.65 \%$ incidence rate of RE. However, a study on Korean subpopulation conducted by Kim et al. reported less than 1\% prevalence of RE in lower second molar [12]. In 2D conventional radiographs RE is not easily detected due to overlapping by other anatomical structures and geometric distortion. On the other hand, CBCT radiographs provides a reliable, non-invasive, and accurate tool for diagnosis of RE cases, as RE can appear clearly in the axial view without any overlapping [15]. 
Scouting of the canal orifices was done using noninvasive E15D ultrasonic tip. Despite of precurving of C-plus files during negotiation of the root canals, ledges had been formed. This may be attributed to the stiffness of C-plus files in addition to the complex and abrupt curvatures of the root canals. This is in agreement with studies reported that ledges and perforations are among complications of using stainless steel C-plus (C-plus file) in canals negotiation due to high buckling resistance [16]. Other study recommended using of nickel titanium glide path files rather than stainless steel files in narrow curved canals because of its inferior property in buckling resistance and bending stiffness [17]. Revo-S rotary system was used for root canal instrumentation due to its asymmetrical triangular cross section which makes the file has less contact with the canal walls in the apical third [18]. In addition to maintaining severe curvatures of the root canals with less canal transportation [19].

Following chemo-mechanical preparation, passive ultrasonic irrigation has been used to active $5.25 \%$ sodium hypochlorite irrigating solution. Studies reported superior tissue dissolving power and canal debridement in case of necrotic pulp when passive ultrasonic activation of sodium hypochlorite was accompanied with breakdown of formed bubbles and deeper penetration of the irrigating solution into hard to reach areas for further cleaning $[20,21]$. Regarding obturation of the root canal system, continuous wave compaction has been used for better obliteration of the root canal system with heated gutta percha in comparison to lateral compaction technique [22].

\section{References}

1. Cantatore G, Berutti E, Castellucci A (2009) Missed anatomy: frequency and clinical impact. Endod Top 15(1): 3-31.

2. CarabelliG.

3. Patel S, Durack C, Abella F, Roig M, Shemesh H, et al. (2014) European Society of Endodontology position statement: The use of CBCT in Endodontics. Int Endod J 47(6): 502-504.

4. Witherspoon DE, Small JC, Regan JD (2013) Missed canal systems are the most likely basis for endodontic retreatment of molars. Tex Dent 130(2): 127-139.

5. Calberson FL, De Moor RJ, Deroose CA (2007) The Radix Entomolaris and Paramolaris: Clinical Approach in Endodontics. J Endod 33(1): 5863.

6. Carlsen O, Alexandersen V (1990) Radix entomolaris: identification and morphology. Scand J Dent Res 98(5): 363-373.

7. Souza-Flamini LE, Leoni GB, Chaves JFM, Versiani MA, Cruz-Filho AM, et al. (2014) The radix entomolaris and paramolaris: A micro- computed tomographic study of 3-rooted mandibular first molars. Endod 40(10): 1616-1621.

8. Sperber GH, Moreau JL (1998) Study of the number of roots and canals in Senegalese first permanent mandibular molars 31(2): 117-122.

9. Tratman EK (1938) Three-rooted lower molars in man and their racial distribution. Br Dent J 64(264): 74.

10. Curzon ME (1973) Three-Rooted Mandibular Permanent Molars in English Caucasians. J Dent Res 52(1): 181.

11. Ferraz JA, Pécora JD (1993) Three-Rooted Mandibular Molars in Patients of Mongolian, Caucasian and Negro Origin. Braz Dent J 3(2): 113-117.

12. Song JS, Choi HJ, Jung IY, Jung HS, Kim SO (2010) The Prevalence and Morphologic Classification of Distolingual Roots in the Mandibular Molars in a Korean Population. J Endod 36(4): 653-657.

13. Pedersen PO, Denmark, Reitzel CA (1949) The East Greenland Eskimo Dentition, numerical variations and anatomy. Amcer j of DO 36(6): 469-470.

14. Younes SA, al-Shammery AR, el-Angbawi MF(1990) Three-rooted permanent mandibular first molars of Asian and black groups in the Middle East. Oral Surg Oral Med Oral Pathol 69(1):102-105.

15.López-Rosales E, Castelo-Baz P, De Moor R, Ruíz-Piñón M, MartínBiedma B, et al. (2015) Unusual root morphology in second mandibular molar with a radix entomolaris, and comparison between cone-beam computed tomography and digital periapical radiography: a case report. J Med Case Rep 22(9): 201.

16. Lopes HP, Elias CN, Mangelli M, Lopes WS, Amaral G, et al. (2012) Buckling Resistance of Path finding Endodontic Instruments. J Endod 38(3): 402-404.

17. Kwak SW, Ha JH, Lee W, Kim SK, Kim HC (2014) Buckling resistance, bending stiffness and torsional resistance of various instruments for canal exploration and glide path preparation. Restor Dent Endod 39(4): 270-275.

18. Medha A, Patil S, Hoshing U, Bandekar S (2014) Evaluation of Forces Generated on Three Different Rotary File Systems in Apical Third of Root Canal using Finite Element Analysis. J Clin Diagn Res 8(1): 243246.

19. Celik D, Taşdemir T, Er K (2013) Comparative Study of 6 Rotary Nickel-Titanium Systems and Hand Instrumentation for Root Canal Preparation in Severely Curved Root Canals of Extracted Teeth. J Endod 39(2): 278-282.

20. Al-Jadaa A, Paqué F, Attin T, Zehnder M (2009) Necrotic pulp tissue dissolution by passive ultrasonic irrigation in simulated accessory canals: impact of canal location and angulation. Int Endod J 42(1): 5965.

21. Martin H, Cunningham W (1985) Endosonics - The ultrasonic synergistic system of endodontics. Dent Traumatol 1(6): 201-206.

22. Jacobson HL, Xia T, Baumgartner JC, Marshall JG, Beeler WJ (2002) Microbial Leakage Evaluation of the Continuous Wave of Condensation. J Endod 28(4): 269-271. 


\section{Your next submission with Juniper Publishers} will reach you the below assets

- Quality Editorial service

- Swift Peer Review

- Reprints availability

- E-prints Service

- Manuscript Podcast for convenient understanding

- Global attainment for your research

- Manuscript accessibility in different formats

( Pdf, E-pub, Full Text, Audio)

- Unceasing customer service

Track the below URL for one-step submission https://juniperpublishers.com/online-submission.php 